\title{
Heavy Metals Accumulation in Soil and Mango Leaf and Their Effects on Soil Microbial Population along Road Sides in Southwest, Nigeria
}

\author{
Adelasoye, K. A. and Oyeyiola, Y. B \\ ${ }^{1}$ Department of Crop and Environmental Protection, Ladoke Akintola University of Technology, Ogbomoso, \\ Nigeria \\ ${ }^{2}$ Department of Crop Production and Soil, Ladoke Akintola University of Technology, Ogbomoso, Nigeria
}

\begin{abstract}
This study examined microbial population (MP) and heavy metal load in the soil and mango leaf, along Ogbomoso-Oyo road (high traffic density) and Ogbomoso-Ifeodan (low traffic density). Mango leaves (about $3 \mathrm{~m}$ from the ground) were sampled at three spots (10km intervals) and three distances of 0-10, 10-20 and $20-30 \mathrm{~m}$ from the edge of the road. Soil was sampled at 0-15 and 15-30 cm depth under mango trees. The samples were analyzed for $\mathrm{Pb}, \mathrm{Cd}, \mathrm{Cr}, \mathrm{Zn}$ with atomic absorption spectrophotometer and total MP using nutrient media preparations. On the High Traffic Density (HTD) road, 20-30m distance, the soil contained

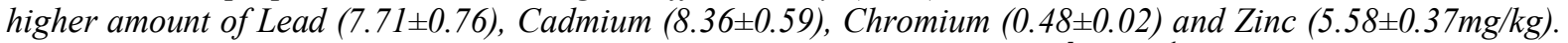
MP was higher at $0-10 \mathrm{~m}$ with Total microbial count of $10.5 \pm 1.46 \times 10^{5} \mathrm{Cfug}^{-1}$ and Total fungi count of $0.83 \pm 0.23 \times 10^{5} \mathrm{Cfug}^{-1}$. Microbial population was higher along LTD than HTD road. Mango leaf contained significantly higher metal content along HTD road Pb (4.31), Cd (4.63), Cr (0.03) and $\mathrm{Zn}$ (5.04mg/kg) than LTD road. Microbial population was higher at LTD than HTD, and Mango accumulated higher heavy metals at HTD than LTD. Implications of heavy metals and microbial populations on food chain were discussed.
\end{abstract}

Keywords: Heavy metal, microbial population, Mango, Nutrient media, traffic densities,

\section{Introduction}

Pollution of the biosphere by heavy metals due to industrial, agriculture, domestic and social activities has created a serious problem for the safe and rational utilization of soils [1,2,3,4,5]. Motor vehicle emission is one of the leading causes of air pollution. Exhaust emission and burning of fossil fuel were identified as primary sources of atmospheric metallic burden [6]. Man, animals, vegetation and soil act as 'Sinks' for atmospheric pollutants $[7,8]$.

In general, an increase in metal concentration adversely affects soil microbial properties such as respiration rate, enzyme activities, which appears to be very useful indicators of soil pollution $[9,10]$. Heavy metals exert toxic effects on soil microorganisms [11], hence, results in the change of diversity, population size and overall activities of the soil microbial communities [12]. There is increasing public concern about health effects resulting from ingestion of food containing toxic metals such as cadmium and lead. A wide range of metabolic disorders and neuropsychological deficits in children have been noted, and chronic exposure to cadmium has been linked to kidney failure and bone disease.

Plants have a higher capacity to take up metals from soils or atmosphere than their physiological needs. While this may not have any adverse effect on plant itself, it may expose the consumer to higher intake of concerned metals. Since plants are the major source of human food, a study of metal-content in plants and crops indicates the extent of heavy metal contamination in human beings by consuming them [13]. It has been reported that nearly half of the mean ingestion of lead, cadmium and mercury through food is due to plant origin (fruit, vegetables and cereals). Several studies revealed that $60-80 \%$ of heavy metal toxins found in urban areas were the results of consuming contaminated foods rather than air pollution [14]. Nigerian roads are characterized by farm sites with all types of crops on the edge of the roads. This study examined the effects of traffic densities on lead $(\mathrm{Pb})$, Cadmium $(\mathrm{Cd})$, Chromium $(\mathrm{Cr})$ and Zinc $(\mathrm{Zn})$ concentrations in soil and mango leaf, and the affects of these metals on microbial population along two roads in Ogbomoso.

\section{Materials and methods}

The study was conducted in Ogbomoso (Longitude $4^{\circ} 10^{\prime} \mathrm{E}$, Latitude $8^{\circ} 10^{\prime} \mathrm{N}$ and altitude $213 \mathrm{~m}$ asl) Oyo state, Nigeria in July, 2010. The main socio-economic activities along the roads are farming and trading farm produce. One major and minor road were chosen for the study, Ogbomoso-Oyo as high traffic density (HTD) and Ogbomoso-Ife Odan road as low traffic density (LTD) in Oyo state. 


\subsection{Collection and preparation of samples}

Soil (0-15 and 15-30 cm depth under mango trees) and mango leaf (about $3 \mathrm{~m}$ from the ground) samples were collected from the road edge along three transects inward within 0-10, 10-20 and 20-30m away from the road sides. The samplings were replicated thrice along the roads at intervals of $10 \mathrm{~km}$. Ten core soil samples randomly distributed round the observation points were taken with soil auger. The soil and mango leaf samples were analyzed for lead $(\mathrm{Pb})$, Cadmium $(\mathrm{Cd})$, Chromium $(\mathrm{Cr})$, Zinc $(\mathrm{Zn})$ and soil $\mathrm{pH}$ and Total microbial population. Sample analyses were carried out by spectrophotometer MILTON ROY 2ID.

The soil samples were air dried and sieved with $2 \mathrm{~mm}$ sieve. The air dried soil sample was weighed for wet digestion. The samples were oven-dried at $70^{\circ} \mathrm{C}$ to constant weight, ground inside a hammer mill incorporated with $2 \mathrm{~mm}$ sieve. $2 \mathrm{~g}$ of the ground samples was then put in crucible and ashed inside furnace at $580^{\circ} \mathrm{C}$. The ash was washed into $100 \mathrm{ml}$ volumetric flask and wet digested with a mixture of 1:1 perchloric acid and nitric acid. The digested samples were then read from a MILTON ROY 2ID Atomic Absorption Spectrophotometer (AAS) using their respective lamp and wavelengths. Calculation was done using: Meter Reading x slope $\mathrm{x}$ Dilution Factor [15].

Standard methods were used to prepare nutrient agar (NA) and potato dextrose agar (PDA) for estimation of microbial population. One gramme each of the soil samples were measured into the test tube containing $9 \mathrm{ml}$ sterile distilled water and serially diluted to dilution factor $\left(10^{-5}\right)$ and $1 \mathrm{ml}$ of the last dilution was put into sterile plate which were incubated at $37^{\circ} \mathrm{C}$ for NA and PDA incubated at $28^{\circ} \mathrm{C}-30^{\circ} \mathrm{C}$. All plates were incubated inverted wise. The plates were counted at $48 \mathrm{hrs}$ for NA and $72 \mathrm{hrs}$ for PDA.

\section{Results}

The $\mathrm{pH}$ of the soil samples from the sites ranges from 6.40 to 6.70 for low traffic density road and 6.60 to 6.90 for high traffic density road and are said to be slightly acidic.

The results of heavy metals extracted from the soil under mango trees sampled were presented in the Table 1 below. Only zinc was significantly higher at high traffic density (HTD) $(5.33 \mathrm{mg} / \mathrm{kg})$ than low traffic density (LTD) $(4.06 \mathrm{mg} / \mathrm{kg})$ road. The total microbial count and the total fungi count were not significantly different at both traffic situations $(\mathrm{P}=0.05)$ (Table 1$)$.

Table 1 Heavy metal concentrations in soil and microbial population along roadsides with different traffic densities

\begin{tabular}{|c|c|c|c|c|c|c|}
\hline \multirow[b]{2}{*}{$\underline{\text { Traffic }}$} & \multicolumn{3}{|c|}{ METALS (mg/kg) } & \multirow[b]{2}{*}{$\mathrm{Zn}$} & \multicolumn{2}{|c|}{ Microbial counts (Cfug1 $\left.\left(\mathrm{x} 10^{5}\right)\right)$} \\
\hline & $\mathrm{Pb}$ & $\mathrm{Cd}$ & $\mathrm{Cr}$ & & Tmc & Tfc \\
\hline High & $6.71 \mathrm{a}$ & $7.87 \mathrm{a}$ & $0.46 \mathrm{a}$ & $5.33 \mathrm{a}$ & $9.48 \mathrm{a}$ & $0.74 \mathrm{a}$ \\
\hline Low & $6.95 \mathrm{a}$ & $7.84 \mathrm{a}$ & $0.39 \mathrm{a}$ & $4.06 \mathrm{~b}$ & $9.67 \mathrm{a}$ & $0.64 \mathrm{a}$ \\
\hline
\end{tabular}

Numbers in column followed by the same letters are not significantly different.

Tmc $=$ Total microbial count

$\mathbf{T f c}=$ Total fungi count $\quad$ Cfug $^{-1}=$ Colony forming unit per gramme

Generally, all the metals $(\mathrm{Pb}, \mathrm{Cd}, \mathrm{Cr}$, and $\mathrm{Zn}$ ) were significantly higher at 20-30m distance from the road edge than $10-20 \mathrm{~m}$ and $0-10 \mathrm{~m}$ (Table 2). The total microbial count and total fungal count were higher near the road $(0-10 \mathrm{~m})$ than far away $(20-30 \mathrm{~m})$ from the road. $(\mathrm{P}=5 \%)$ (Table 2$)$.

Table 2 Heavy metal concentrations in soil and microbial population under mango trees along roadsides with different distances from the road

\begin{tabular}{|c|c|c|c|c|c|c|}
\hline \multirow[b]{2}{*}{ Distance } & \multicolumn{3}{|c|}{ METALS (mg/kg) } & \multicolumn{3}{|c|}{ Microbial counts } \\
\hline & $\mathrm{Pb}$ & $\mathrm{Cd}$ & $\mathrm{Cr}$ & $\mathrm{Zn}$ & $\operatorname{Tmc} \mathrm{Cfug}^{1}\left(\mathrm{x} 10^{5}\right)$ & $\operatorname{TfcCfug}^{1}\left(\mathrm{x} 10^{5}\right)$ \\
\hline $0-10 \mathrm{~m}$ & $5.98 \mathrm{c}$ & $7.25 \mathrm{c}$ & $0.43 \mathrm{ab}$ & $4.22 b$ & $10.78 \mathrm{a}$ & $0.88 \mathrm{a}$ \\
\hline $10-20 \mathrm{~m}$ & $6.73 b$ & $7.89 b$ & $0.41 \mathrm{ab}$ & $4.90 \mathrm{a}$ & $10.52 \mathrm{a}$ & $0.68 \mathrm{~b}$ \\
\hline $20-30 \mathrm{~m}$ & $7.78 \mathrm{a}$ & $8.42 \mathrm{a}$ & $0.44 b$ & $4.97 \mathrm{a}$ & $7.42 b$ & $0.50 \mathrm{c}$ \\
\hline
\end{tabular}

Numbers in column followed by the same letters are not significantly different. 
Tmc $=$ Total microbial count $\quad$ Tfc $=$ Total fungi count

Cfug $^{-1}=$ Colony forming unit per gramme

The microbial populations were higher at $0-15 \mathrm{~cm}$ than $15-30 \mathrm{~cm}$ depth (Table 3). Soils from $15-30 \mathrm{~cm}$ depth under mango trees contained significantly higher $\mathrm{Pb}, \mathrm{Cd}$, and $\mathrm{Zn}$ than $0-15 \mathrm{~cm}$ (Table 3 ).

Table 3 Heavy metal concentrations soil and microbial population under mango tree along roadsides with different soil depths

\begin{tabular}{|c|c|c|c|c|c|c|}
\hline \multirow[b]{2}{*}{ Soil depth } & \multirow[b]{2}{*}{$\mathrm{Pb}$} & \multicolumn{2}{|c|}{ METAL (mg $\mathrm{kg}$ ) } & \multicolumn{3}{|c|}{ Microbial counts } \\
\hline & & $\mathrm{Cd}$ & $\mathrm{Cr}$ & $\mathrm{Zn}$ & $\operatorname{Tmc}\left(\mathrm{x} 10^{5}\right) \mathrm{Cfug}^{1}$ & $\operatorname{Tfc}\left(\mathrm{x} 10^{5}\right) \mathrm{Cfug}^{1}$ \\
\hline $0-15 \mathrm{~cm}$ & $6.55 b$ & $7.66 \mathrm{~b}$ & $0.43 a$ & $4.61 b$ & $10.89 a$ & $0.82 a$ \\
\hline $15-30 \mathrm{~cm}$ & $7.11 \mathrm{a}$ & $8.05 a$ & $0.43 b$ & $4.78 \mathrm{a}$ & $8.26 \mathrm{~b}$ & $0.56 b$ \\
\hline
\end{tabular}

Numbers in column followed by the same letters are not significantly different.

Tmc $=$ Total microbial count

Tfc $=$ Total fungi count

Cfug $^{-1}=$ Colony forming unit per gramme

Mango leaves at HTD contained significantly more lead, cadmium, and zinc while chromium was higher at LTD (Table 4).

Table 4 Heavy metal concentrations in mango leaf along roadsides with different Traffic densities.

\begin{tabular}{llccc}
\hline & \multicolumn{4}{c}{ Metal $(\mathrm{mg} / \mathrm{kg})$} \\
\cline { 2 - 5 } Traffic & $\mathrm{Pb}$ & $\mathrm{Cd}$ & $\mathrm{Cr}$ & $\mathrm{Zn}$ \\
\hline High & $4.31 \mathrm{a}$ & $4.63 \mathrm{a}$ & $0.03 \mathrm{~b}$ & $5.04 \mathrm{a}$ \\
Low & $3.24 \mathrm{~b}$ & $3.76 \mathrm{~b}$ & $0.07 \mathrm{a}$ & $3.91 \mathrm{~b}$
\end{tabular}

Values in the column followed by the same letters are not significantly different.

Generally, there were no significant differences in heavy metal content of mango leaves considering the distance from the edge of the road (Table 5).

Table 5 Heavy metal concentrations in mango leaf along roadsides with different distances from the edge of the road

\begin{tabular}{lllll}
\hline & \multicolumn{4}{c}{ Metal $(\mathrm{mg} / \mathrm{kg})$} \\
\cline { 2 - 4 } Distances & $\mathrm{Pb}$ & $\mathrm{Cd}$ & $\mathrm{Cr}$ & $\mathrm{Zn}$ \\
\hline $0-10 \mathrm{~m}$ & $4.01 \mathrm{a}$ & $4.40 \mathrm{a}$ & $0.06 \mathrm{a}$ & $4.53 \mathrm{a}$ \\
$10-20 \mathrm{~m}$ & $3.58 \mathrm{a}$ & $4.00 \mathrm{a}$ & $0.05 \mathrm{ab}$ & $4.63 \mathrm{a}$ \\
$20-30 \mathrm{~m}$ & $3.74 \mathrm{a}$ & $4.19 \mathrm{a}$ & $0.04 \mathrm{~b}$ & $4.29 \mathrm{a}$ \\
\hline
\end{tabular}

Numbers in column followed by the same letters are not significantly different.

The average metal concentration of mango leaf $(\mathrm{mg} / \mathrm{kg})$ at different distances from the road is shown in Table 6. There is inconsistence in the concentration of metals in mango leaves in relation with distance from the edge of the roads.

Table 6 Average metal concentration in mango leaf along roadsides with different distances from the road 
Heavy Metals Accumulation in Soil and Mango Leaf and Their Effects on Soil Microbial ....

\begin{tabular}{ccccc}
\hline \multirow{2}{*}{$\begin{array}{l}\text { Level of traffic } \\
\text { And distance }\end{array}$} & \multicolumn{5}{c}{ Metal $( \pm \mathrm{SD})(\mathrm{mg} / \mathrm{kg})$} \\
\cline { 2 - 5 } & $\mathrm{Pb}$ & $\mathrm{Cd}$ & $\mathrm{Cr}$ & $\mathrm{Zn}$ \\
\hline $\mathrm{Ha}$ & $4.59 \pm 0.02$ & $4.51 \pm 0.20$ & $0.03 \pm 0.00$ & $5.15 \pm 0.55$ \\
$\mathrm{Hb}$ & $4.00 \pm 0.70$ & $4.30 \pm 0.60$ & $0.03 \pm 0.00$ & $5.17 \pm 1.07$ \\
$\mathrm{Hc}$ & $4.32 \pm 0.42$ & $4.69 \pm 0.34$ & $0.02 \pm 0.00$ & $4.80 \pm 0.51$ \\
$\mathrm{La}$ & $3.42 \pm 0.52$ & $3.00 \pm 0.50$ & $0.10 \pm 0.03$ & $3.90 \pm 0.20$ \\
$\mathrm{Lb}$ & $3.15 \pm 0.45$ & $3.70 \pm 0.20$ & $0.07 \pm 0.01$ & $4.00 \pm 0.55$ \\
$\mathrm{Lc}$ & $3.16 \pm 0.51$ & $3.69 \pm 0.27$ & $0.05 \pm 0.00$ & $3.78 \pm 0.22$
\end{tabular}

Key: $\mathbf{H}=$ high traffic

$\mathbf{L}=$ low traffic $\quad \mathbf{a}=0-10 \mathrm{~m}$

$\mathbf{b}=10-20 \mathrm{~m} \mathbf{c}=20-30 \mathrm{~m}$

At HTD road, 20-30m from the edge of the road, the soil contained higher amount of lead (7.71 \pm $0.76 \mathrm{mg} / \mathrm{kg}), \mathrm{Cd}(8.36 \pm 0.59), \mathrm{Cr}(0.48 \pm 0.02)$ and $\mathrm{Zn}(5.58 \pm 0.37 \mathrm{mg} / \mathrm{kg})$ than the region closer (Table 7). Table 7 showed the microbial content along the two roads with the distances from the edge of the road. The microbial population showed the reverse order with higher population recorded near the road $(0-10 \mathrm{~m})$ with total microbial count of $10.50 \pm 1.46 \times 10^{5} \mathrm{Cfug}^{-1}$ and total fungal count of $0.83 \pm 0.23 \times 10^{5} \mathrm{Cfug}^{-1}$. The same trend was observed at LTD. However, microbial population was slightly higher along the low traffic than the high traffic road.

Table 7. Average metal concentration of soil and microbial population under mango tree at different distances from the road

\begin{tabular}{|c|c|c|c|c|c|c|}
\hline \multirow{2}{*}{$\begin{array}{l}\text { Level of Traffic } \\
\text { And distance }\end{array}$} & \multicolumn{4}{|c|}{ Metals $( \pm \mathrm{SD})(\mathrm{mg} / \mathrm{kg})$} & \multirow{2}{*}{$\begin{array}{c}\text { Tmc } \\
\text { Cfug }\left(\times 10^{5}\right) \\
\end{array}$} & \multirow{2}{*}{$\begin{array}{c}\text { Tfc } \\
\text { Cfug }^{-1}\left(\times 10^{5}\right) \\
\end{array}$} \\
\hline & $\mathrm{Pb}$ & $\mathrm{Cd}$ & $\mathrm{Cr}$ & $\mathrm{Zn}$ & & \\
\hline $\mathrm{Ha}$ & $5.58 \pm 0.48$ & $6.95 \pm 0.54$ & $0.45 \pm 0.12$ & $4.73 \pm 0.32$ & $10.50 \pm 1.46$ & $0.83 \pm 0.23$ \\
\hline $\mathrm{Hb}$ & $6.91 \pm 0.40$ & $8.29 \pm 0.67$ & $0.44 \pm 0.05$ & $5.69 \pm 0.51$ & $10.29 \pm 2.02$ & $0.85 \pm 0.26$ \\
\hline $\mathrm{Hc}$ & $7.71 \pm 0.76$ & $8.36 \pm 0.59$ & $0.48 \pm 0.02$ & $5.58 \pm 0.37$ & $7.64 \pm 0.97$ & $0.53 \pm 0.10$ \\
\hline La6. & $6.46 \pm 0.82$ & $7.55 \pm 0.71$ & $0.40 \pm 0.10$ & $3.71=0.43$ & $11.07 \pm 3.07$ & $0.93=0.52$ \\
\hline $\mathrm{Lb}$ & $6.55 \pm 1.06$ & $7.48 \pm 1.09$ & $0.39 \pm 0.08$ & $4.10 \pm 0.47$ & $10.75 \pm 2.59$ & $0.52 \pm 0.08$ \\
\hline $\mathrm{Lc}$ & $7.85 \pm 0.47$ & $8.47 \pm 0.47$ & $0.40 \pm 0.04$ & $4.37 \pm 0.36$ & $7.21 \pm 1.01$ & $0.47 \pm 0.08$ \\
\hline
\end{tabular}

Key: $\mathbf{H}=$ high traffic $\quad$ Tmc $=$ Total viable count

$\mathbf{L}=$ low traffic $\quad \mathbf{T f} \mathbf{c}=$ Total fungi count

$\mathbf{a}=0-10 \mathrm{~m} \quad \mathbf{C f u g}^{-1}=$ Colony forming unit per gramme

$\mathbf{b}=10-20 \mathrm{~m} \mathbf{c}=20-30 \mathrm{~m} \quad \mathrm{SD}=$ Standard Deviation.

At $0-15 \mathrm{~cm}$ depth along the HTD road, all the metals were lower in quantity than at $15-30 \mathrm{~cm}$ depth. The only exception was the chromium recorded at $10-20 \mathrm{~m}$ along the road where higher $\mathrm{Cr}(0.46 \pm 0.07 \mathrm{mg} / \mathrm{kg}) \mathrm{was}$ recorded, and $20-30 \mathrm{~m}$ with higher $\mathrm{Zn}(5.84 \pm 0.05 \mathrm{mg} / \mathrm{kg})$. The same trend was observed at LTD at $10-20 \mathrm{~m}$ distance from the road edge for $\mathrm{Pb}, \mathrm{Cd}$, and $\mathrm{Zn}$. Chromium recorded higher amount, $0.42 \pm 0.11$ and $0.39 \pm 0.05 \mathrm{mg} / \mathrm{kg}$ than $0.38 \pm 0.11$ and $0.38 \pm 0.02 \mathrm{mg} / \mathrm{kg}$ respectively for $0-15 \mathrm{~cm}$ depth and $15-30 \mathrm{~cm}$ at $0-10$ and 10-20m distance from the road. At 20-30m distance from the edge of the LTD road, $0-15 \mathrm{~cm}$ depth recorded higher metal content than $15-30 \mathrm{~cm}$ for $\mathrm{Pb}, \mathrm{Cd}, \mathrm{Cr}$ and $\mathrm{Zn}$ (Table 8). Table 8 showed the microbial population in the soil according to depth of sampling along the two roads. Total microbial count and total fungi count of the microbial population were higher at $0-15 \mathrm{~cm}\left(7.47 \pm 1.21 \times 10^{5} \mathrm{Cfug}^{-1}\right)$ than $15-30 \mathrm{~cm}\left(6.94 \pm 0.95 \times 10^{5} \mathrm{Cfug}^{-1}\right)$ depth throughout the experimental sites and the depth of soil sampling. Microbial populations were a little higher at low traffic density than high traffic density road.

Table 8. Average metal concentrations in soil and microbial population at different depths under mango tree along roadsides with different distances from the road.

\begin{tabular}{|c|c|c|c|c|c|c|}
\hline Distance and soil depth & $\mathrm{Pb}$ & $\mathrm{Cd}$ & $\mathrm{Cr}$ & $\mathrm{Zn}$ & $\begin{array}{c}\text { Tmc } \\
\text { Cfug }^{1}\left(\times 10^{5}\right)\end{array}$ & $\begin{array}{c}\text { Tfc } \\
\text { Cfug }^{1}\left(\times 10^{5}\right)\end{array}$ \\
\hline $\mathrm{Had}_{1}$ & $5.10 \pm 0.26$ & $6.60 \pm 0.10$ & $0.44 \pm 0.14$ & $4.55 \pm 0.35$ & $11.63 \pm 1.20$ & $1.00 \pm 0.20$ \\
\hline $\mathrm{Had}_{2}$ & $5.90 \pm 0.18$ & $7.30 \pm 0.60$ & $0.48 \pm 0.13$ & $4.90 \pm 0.20$ & $9.37 \pm 0.25$ & $0.67 \pm 0.06$ \\
\hline $\mathrm{Hbd}_{1}$ & $6.56 \pm 0.15$ & $7.93 \pm 0.65$ & $0.46 \pm 0.07$ & $5.35 \pm 0.35$ & $11.53 \pm 2.10$ & $1.00 \pm 0.30$ \\
\hline $\mathrm{Hbd}_{2}$ & $7.27 \pm 0.05$ & $8.65 \pm 0.55$ & $0.43 \pm 0.02$ & $6.03 \pm 0.40$ & $9.04 \pm 1.05$ & $0.70 \pm 0.10$ \\
\hline $\mathrm{Hcd}_{1}$ & $7.25 \pm 0.85$ & $8.20 \pm 0.80$ & $0.46 \pm 0.01$ & $5.84 \pm 0.05$ & $8.14 \pm 1.25$ & $0.60 \pm 0.10$ \\
\hline $\mathrm{Hcd}_{2}$ & $8.17 \pm 0.31$ & $8.51 \pm 0.40$ & $0.50 \pm 0.01$ & $5.32 \pm 0.30$ & $7.13 \pm 0.12$ & $0.47 \pm 0.06$ \\
\hline $\operatorname{Lad}_{1}$ & $5.90 \pm 0.80$ & $7.05 \pm 0.55$ & $0.42 \pm 0.11$ & $3.57 \pm 0.46$ & $13.8 \pm 0.80$ & $1.39 \pm 0.02$ \\
\hline $\mathrm{Lad}_{2}$ & $7 \pm 0.36$ & $8.05 \pm 0.45$ & & & & \\
\hline
\end{tabular}


Heavy Metals Accumulation in Soil and Mango Leaf and Their Effects on Soil Microbial ....

\begin{tabular}{|l|l|l|l|l|l|l|}
\hline & & & $0.38 \pm 0.11$ & $3.85 \pm 0.45$ & $8.37 \pm 1.04$ & $0.47 \pm 0.15$ \\
\hline $\operatorname{Lbd}_{1}$ & $6.45 \pm 1.65$ & $7.50 \pm 1.70$ & $0.39 \pm 0.05$ & $4 \pm 0.51$ & $12.80 \pm 1.51$ & $0.47 \pm 0.06$ \\
\hline $\mathrm{Lbd}_{2}$ & $6.65 \pm 0.25$ & $7.46 \pm 0.23$ & $0.38 \pm 0.02$ & $4.20 \pm 0.50$ & $8.70 \pm 1.35$ & $0.57 \pm 0.06$ \\
\hline $\mathrm{Lcd}_{1}$ & $8.05 \pm 0.65$ & $8.65 \pm 0.65$ & $0.41 \pm 0.06$ & $4.36 \pm 0.44$ & $7.47 \pm 1.21$ & $0.47 \pm 0.12$ \\
\hline $\mathrm{Lcd}_{2}$ & $7.05 \pm 0.05$ & $.30 \pm 0.20$ & $0.38 \pm 0.02$ & $4.37 \pm 0.37$ & $6.94 \pm 0.95$ & $0.47 \pm 0.06$ \\
\hline
\end{tabular}

$$
\begin{aligned}
\text { Key: } \mathbf{H}=\text { high traffic } \quad \text { Tmc }=\text { Total viable count } \\
\mathbf{L}=\text { low traffic } \quad \mathbf{T f c}=\text { Total fungi count } \\
\mathbf{a}=0-10 \mathrm{~m} \quad \mathbf{C f u g} \mathbf{g}^{-1}=\text { Colony forming unit per gramme } \\
\mathbf{b}=10-20 \mathrm{~m} \mathbf{d}_{\mathbf{1}}=0-15 \mathrm{~cm} \quad \mathbf{d}_{\mathbf{2}}=\mathbf{1 5 - 3 0} \mathbf{c m} \\
\mathbf{c}=20-30 \mathrm{~cm} \mathrm{SD}=\text { Standard Deviation }
\end{aligned}
$$

\section{Discussion}

The results indicated that mango leaves contained the investigated heavy metals $\mathrm{Pb}, \mathrm{Cd}, \mathrm{Cr}$ and $\mathrm{Zn}$. Jaya [16] reported that the concentration of heavy metals, lead and cadmium in raw mangoes (fruits) were beyond the permissible levels given by WHO [17] for human consumption. The soil content of the metals was higher than that in the mango leaves along both roads. Microbial populations were also affected adversely as indicated by the lower microbial population recorded where higher metal concentrations abound. Nwuche [18] reported additive or synergistic effects of metals on soil microbes in that the effect of $\mathrm{Zn}$ alone was not significant on the activities of soil microbes but in combination with copper, it engenders a more toxicological effect than even copper itself.

The change in the metal concentrations with distance from the edge of the road was not consistent as reported by different authors. These results agreed with that of Voegborlo [19] who reported clearly defined gradients of lead contamination beside roadways, and less-defined gradients of other metals including cadmium, chromium, copper, nickel, vanadium, and zinc. Variations in the concentration of heavy metals in soil profiles are normally not consistent and readily interpreted because a number of factors can influence the level of metals in a soil profile and these include nature of parent material, the organic matter content environmental factors and chemical properties of the soil as well as the metal solubility. Soil $\mathrm{pH}$ greatly influences the solubility, availability and toxicity of metal elements in the soil [20]. It has been reported that a neutral soil may contain high levels of $\mathrm{Mn}, \mathrm{Al}$ or $\mathrm{Pb}$ without any sign of toxicity to microorganisms whereas toxicity may develop with certain organisms at much lower metal concentrations in acid soils [21]. Thus, if appropriate $\mathrm{pH}$ for maximum dissolution of a metal is not in place, the toxicity of such metal would be seriously hindered, if not entirely stopped. In heavy-metal-polluted soils, plant growth can be inhibited by metal absorption. However, some plant species are able to accumulate fairly large amounts of heavy metals without showing stress which represents a potential health risk for animals and humans [23].

Toxic effects of heavy metals on micro-organisms manifest in numerous ways such as decrease in litter decomposition and nitrogen fixation, less efficient nutrient cycling [24], impaired enzyme synthesis and activity in soil, sediments and water. It has been reported that the rate of mineralization of acid forest soils decreased inversely with the $\log$ of the heavy metal concentration [20,21]. Synergism was reported by $[25,26]$ as responsible for the inhibition of soil-litter respiration by a combination of Se and Cd. Chander [27]) also reported that $\mathrm{Cu}$ and $\mathrm{Zn}$ in combination caused larger decreased in soil microbial biomass compared to the sum of either metals alone. These may eventually result in yield depression. Heavy metal uptake by crops growing in contaminated soil such as road side soil is a potential hazard to human health because of transmission in the food chain $[28,29,30]$.

It has been reported that prolonged consumption of sub-lethal concentrations of heavy metals through food may lead to their chronic accumulation which hinder proper functioning of the kidney and liver of humans thereby causing disruption of numerous biochemical processes, leading to cardiovascular, nervous, kidney and bone diseases [31,32, 33, 34, ]. Zhang [35] findings indicate that trees growing linearly along roadways can effectively reduce the heavy metals' concentrations

Continuous deposition of these heavy metals indicates potential health risk for human through the food chain.

Chronic exposure to metals at high enough level to cause chronic toxicity effects (such as hypertension in individuals exposed to lead, and renal toxicity in individuals exposed to cadmium) can occur without symptoms. Several studies have revealed that $60-80 \%$ of heavy metal toxins found in human bodies in urban areas were due to consumption of contaminated foods rather than air pollution [14]. The European Union ranged $\mathrm{Cd}$ in soil of $0-1 \mathrm{mg} / \mathrm{kg}$ indicated non-contaminated soil, $1-3 \mathrm{mg} / \mathrm{kg}$ indicated slight contamination and 3$10 \mathrm{mg} / \mathrm{kg}$ indicated a contaminated soil. Thus, both the high and low traffic density roads assessed in this study were contaminated in terms of cadmium. FAO/WHO recommended maximum tolerable intake of Cd of 0.4$0.5 \mathrm{mg} / \mathrm{kg}$ per week or equal to $0.07 \mathrm{mg}$ per day. The Korean women were estimated in 2007 to take $14.82 \mathrm{mg}$ $\mathrm{Cd} /$ day of which $9.74 \mu \mathrm{g} \mathrm{Cd} /$ day was from plant foods and $5.09 \mu \mathrm{g} \mathrm{Cd} /$ day was from animal source. The daily cadmium intake of plant origin accounted for $65.7 \%$ [36]. 
The results of this study when compared with the WHO/FAO standard lower limits of $\mathrm{Pb}(0.3 \mathrm{mg} / \mathrm{kg})$, $\mathrm{Cd}(0.2 \mathrm{mg} / \mathrm{kg})$ and $\mathrm{Cr}(0.05 \mathrm{mg} / \mathrm{kg})$ indicated that both the soil and mango trees along both roads were contaminated with heavy metals. The health implications of this are enormous and there is the need to educate policy makers, scientists and general public about toxicity of heavy metals. Agricultural activities should be discouraged within 30 meter from road edge so also is animal grazing if heavy metal exposure routes are to be reduced to the barest minimum.

\section{References}

[1]. R., D. Strivastava, Kumar and S.K. Gupta. Municipal Sludge-induced Phytotoxicity. ATLA., 33,2005, 501-508

[2]. S.V. Avery. Metal toxicity in yeasts and the role of oxidative stress. Adv Appl Microbiol. 49, $2001,111-142$.

[3]. J.C., Igwe, Nnorom, B, and B.C.G. Gbaruko. Kinetics of radionuclide and heavy metals Behavior in soils: Implications for plant growth. African Journal of Biotechnology, 4(B), 2005,1541-1547.

[4]. K., H. Kandori, Nakashima and T. Ishikawa. Inner structure of uniform spherical metal phosphate particles, Journal of Colloid and Interface Science, 1993, 160: 499.

[5]. B. Volesky. Biosorption of heavy metals. CRS Press, Boston, 1990

[6]. D.S. Aribike. Environmental Impacts of Industrialization in Nigeria: A treatise. Paper Presented at the Conference of Nigerian Society of Chemical Engineers, November, 1996, 14-16.

[7]. A.H. Clyde, Vegetation: A sink for atmospheric pollutants. J. Air Pollut. Control Ass. 21, 1971, 341

[8]. O. Osibanjo and Ajayi,S.O. Trace metal levels in tree barks as indicators of atmospheric pollution. Envir. Int. 4, 1980, 239-244.

[9]. P.C. Brooks. The use of microbial parameters in monitoring soil pollution by heavy metals. Biol. Fertil. Soils, 19, 1995, 269-279.

[10]. T., A. Szili-Kovacs, Anton and F. Gulyas. Effect of Cd, Ni, and Cu on some microbial properties of a calcareous Chernosem soil. (Ed.): J. Kubat. In: Proc. $2^{\text {nd }}$ Symp. on the Pathways and Consequences of Dissemination of Pollutants in the Biosphere" Prague, 1999,82-102.

[11]. T.E. Pawloska, and I. Charvat. Heavy Metal Stress and Developmental Pattern of Arbuscular Mycorrhizal Fungi. Appl. Environ. Microbiol., 70 (11), 2004, 6643-6649.

[12]. M., O. Smejkalova, Mikanova and L. Boruvka. Effects of heavy metal concentration on biological activity of soil microorganisms. Plant Soil Environ., 49(7), 2003, 321-326.

[13]. Athar. M and Vohora. S.B. Heavy metals and Environment. New Age International (Pub) 1995, p.216.

[14]. R.F. Quijano. Health Issues in Urban Agriculture. Paper Presented at the National Conference On Urban Agriculture Systems in the Philippines, Quezon City. Philippine, 2001, 15-17 (15)

[15]. J.R. Peer, and Rosen, W.G. Lead and Cadmium content of urban garden vegetable trace subst. Environ.Health. 11, 1977, $399-405$.

[16]. D.S. Jaya. Assessment of heavy metal contamination in the evergreen tree Mangifera indica L. and soils near National Highway-47 in Thiruvananthapuram District, Keral Toxicology International Volume16, 2009, Issue 1 Page $43--47$

[17]. WHO. Evaluation of certain food additives and contaminants. Technical Report No. 837, 1983, Geneva: World Health Organization.

[18]. C.O. Nwuche and Ugoji, E.O. Effects of heavy metal pollution on the soil microbial activity. Int. J. Environ. Sci.Tech., 5 (2), 2008, 409-414. ISSN: 1735-1472.

[19]. R.B. Voegborlo and M.B. Chirgawl. Heavy metal accumulation in roadside soil and vegetation along a major highway in Lybia. Journal of Science and Technology Vol. 27, 2007, No. 3

[20]. E Baath and Arnebrant, K. Growth rate and response of bacterial communities to $\mathrm{pH}$ in limed and ash treated soils. Soil Biol. Biochem., 26 (8) 1994, 995-1001.

[21]. B. Marschner and Kalbitz, K. Control of bioavailability and biodegradation of dissolved organic Matter in soils. Geoderma., 113 (3-4), 2003, 211-235.

[22]. V.P. Utgika; Tabak, H.H.; Haines, J.R. and Govind, R. Quantification of toxic inhibitory impact of copper and zinc on mixed cultures of sulphate reducing bacteria. Biotech. Bioeng., 82 (3), 2003, 306-312.

[23]. M.A. Oliver Soil and human health: a review. Eur. J. Soil Sci. 48 (4), 1997, 573-592.

[24]. E. Baath. Effects of heavy metals on microbial processes and population. Air Soil Pollut.47, 1989, $355-379$.

[25]. B. Lighthart and Bond, H. Design and preliminary results from soil/litter microcosms. Int. J. Environ. Stud., 10 (1), 1976, 51-58.

[26]. J.J. Kelly and Tate, R.L. Effects of heavy metal contamination and remediation on soil microbial Communities in the vicinity of a zinc smelter. J. Environ. Qual.,27 (3), 1998, 609-617.

[27]. K. hander and Brookes, P.C. Residual effects of zinc, copper and nickel in sewage sludge on Microbial biomass in sandy loam. Soil Biol. Biochem., 25 (9), 1993, 1231-1239.

[28]. Brun, L.A., Maillet, J., Hinsinger,P., and Pepin, M. evaluation of copper availability to plants in copper-contaminated vineyard soils. Environ. Pollut. 111, 2001, 293-302.

[29]. R. Ginchio, Rodriguez, P.H., Badila-Ohibaum, R., Allen, H.E. and Lagos, G.E. Effects of soil copper content and pH on copper uptake of selected vegetables grown under Controlled conditions. Environ. Toxicol. Chem. 21, 2002, 1736-1744.

[30]. W. Friesl, Friedl, J.,Platzer, K., Horak, O. and Gerzabek, M.H. Remediation of contaminated agricultural soils near a former Pb/Zn smelter in Austria: batch, pot and field experiments. Environ. Pollut. 144, 2006, 40-50.

[31]. L Jarup. Hazards of heavy metal contamination. Br. Med Bull. 68, 2003, 167-182.

[32]. WHO. Lead environmental health criteria. Geneva: World Health Organization, 1995, p. 165.

[33]. K. Steenland and Boffetta P. Lead and cancer in humans: where are we now? Am. J. Ind. Med. 38, 2000, $295-299$.

[34]. M.A. Radwan and Salama, AK. Market basket survey for some heavy metals in Egyptian fruits and vegetables. Food Chem. Toxicol., 44. 2006. 1273-1278.

[35]. F. Zhang Yan X, Zeng C, Zhang M, Shrestha S, Devkota LP, Yao T. Influence of Traffic Activity on Heavy Metal Concentrations of Roadside Farmland Soil in Mountainous Areas. Int. J. Environ. Res. Public Health 9(5), 2012, 1715-1731.

[36]. Chan-Seok Moon, Chae Kwan Lee, Jung Man Kim, Jong-Min Paik and Masayuki Ikeda Time trends in dietary cadmium intake of Korean women Toxic. Res., 1, 2012, 145-150. 